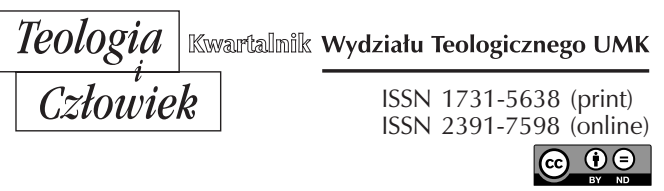

50(2020)2, ss. $259-277$

KS. ADAM KŁONOWSKI

\title{
POBOŻNOŚĆ LUDOWA I DUSZPASTERSTWO ON-LINE JAKO ŚRODKI ODNOWY KOŚCIOŁA W POLSCE
}

DOI: http://dx.doi.org/10.12775/TiCz.2020.027

Streszczenie. Przyglądając się współczesnej rzeczywistości, można dostrzec potrzebę odnowy Kościoła w Polsce. Jej naturalnym źródłem jest odniesie do Bożego Objawienia za pomocą właściwych działań duszpasterskich. Wśród nich autor zwraca uwagę na potrzebę promowania pobożności ludowej oraz wykorzystanie cyberprzestrzeni w dziele ewangelizacji. Obie ze wspomnianych form duszpasterstwa niosą za sobą wiele korzyści. Bazują na prostocie i przystępności, lecz niewłaściwie wykorzystywane, mogą nieść za sobą także konkretne niebezpieczeństwa. Niezbędna jest zatem analiza obu zagadnień i przedstawienie wynikających z niej wniosków, co stanowi treść niniejszej publikacji.

Słowa kluczowe: duszpasterstwo; Internet; pobożność ludowa; odnowa.

Abstract. Folk piety and on-line pastoral care as means of renewal of the Catholic Church in Poland. Considering recent changes of the contemporary world, we may conclude, that there is an urgent need of renewal of the Catholic Church in Poland. These changes can only be introduced by means of appropriate pastoral activities. The author of this article draws the recipient's attention to the above mentioned issues. One of them is the need to promote popular piety and another one is the use of cyberspace to spread evangelization. Both of these forms of pastoral activities bring many benefits. They have an accessible form and are based on simplicity. However, if we use them 
imprudently, they can lead to improper results. In summary, the main purpose of this publication is to analyze both issues and present the resulting conclusions.

Key words: pastoral activity; cyberspace; popular piety; renewal.

Człowiek żyjący w kulturze europejskiej, osadzony w dalece rozwiniętej technologii, bogaty $\mathrm{w}$ niespotykany dotąd potencjał ekonomiczny, posiada wszelkie środki do tego, aby rozwijać swoją pobożność i wiarę w Boga. Obserwacja aktualnej sytuacji duszpasterskiej Kościoła rzymskokatolickiego w Polsce przynosi jednak zgoła inne wnioski. Jako przykład mogą posłużyć badania przeprowadzone w pierwszej połowie 2018 roku przez Główny Urząd Statystyczny. Wynika z nich, że w Mszach świętych i nabożeństwach najrzadziej uczestniczą osoby w wieku 25-34 lata. Oprócz tego między 16 a 24 rokiem życia najwięcej osób deklaruje się jako niewierzące i najmniej jako głęboko wierzące ${ }^{1}$. To właśnie te grupy wiekowe domagają się największej opieki duszpasterskiej i podjęcia właściwych działań stanowiących dla nich pomoc w odkryciu drogi do Boga i Kościoła.

Znaczną przeszkodą w realizacji tych zadań jest fakt, że obywatel współczesnej Europy coraz częściej „jawi się jako słaby, zagubiony, pozbawiony wewnętrznego ośrodka, zły na siebie i na cały świat, zniewolony przez antywartości, oczekujący kogoś, kto nigdy nie przyjdzie, niejako potwierdzając tym fakt, że utraciwszy kontakt z Absolutem, utracił także samego siebie”2. Sytuację zagubienia i niepewności dodatkowo spotęgowała pandemia koronawirusa, która przyczyniła się do ograniczenia możliwości uczestnictwa w nabożeństwach, gromadzenia się na wspólnej modlitwie, a także korzystania z sakramentów. Taki stan rzeczy sprawia, że Kościół

1 Reprezentacyjne badanie spójności społecznej dotyczące życia religijnego mieszkańców Polski zostało przeprowadzone w dniach 05.02-30.05.2018 r. Odpowiedzi na pytania w kwestionariuszu indywidualnym udzieliło ponad 13 tys. osób w wieku 16 lat i więcej. Zob. Główny Urząd Statystyczny, Życie religijne w Polsce. Wyniki badania spójności społecznej 2018, w: https://stat.gov.pl/obszary-tematyczne/inne-opracowania/ wyznania-religijne/zycie-religijne-w-polsce-wyniki-badania-spojnosci-spolecznej-2018,8,1. html (dostęp: 25.05.2020).

2 Jan Paweł II, Grzech jako „alienacja” człowieka, w: tenże, Dzieła zebrane, t. 6, Katechezy, cz. I, Kraków 2007, s. 750. 
w Polsce kolejny raz „zobowiązany jest do badania znaków czasu i ich interpretowania w świetle Ewangelii, tak aby w sposób dostosowany do każdego pokolenia mógł odpowiadać na odwieczne pytania ludzi o sens życia doczesnego i przyszłego oraz ich wzajemną relację"3.

Nietrudno zauważyć, że działania duszpasterskie wobec młodych ludzi potrzebują swoistej odnowy. Naturalnym jej źródłem jest odniesienie do Bożego Objawienia. Jednakże aby osoby dalekie Kościołowi mogły je rzeczywiście poznać i przyjąć, potrzebne jest zastosowanie przystępnych im środków. Jednym z nich może być pobożność ludowa, która stanowi „opatrznościową pomoc w zachowaniu wiary, zwłaszcza tam, gdzie wierni byli pozbawieni opieki duszpasterskiej lub nie przeżyli wystarczająco głębokiej ewangelizacji”".

W XXI wieku nie sposób nie dostrzec również ogromnego potencjału drzemiącego w środkach masowego przekazu, a szczególnie w Internecie, który może stanowić doskonałe narzędzie ewangelizacyjne, motywujące do pogłębienia wiary i pełniejszego przeżywania praktyk religijnych. Obie ze wspomnianych form duszpasterstwa niosą za sobą wiele korzyści. Bazują na prostocie, dostępności i przystępności, ale niewłaściwie stosowane lub źle rozumiane mogą wywołać negatywne skutki. Celem artykułu jest zatem ukazanie pobożności ludowej i duszpasterstwa on-line jako przestrzeni odnowy wiary i religijności młodych ludzi oraz zwrócenie uwagi na niebezpieczeństwa, wynikające z błędnego rozumienia omawianych pojęć.

\section{POTRZEBA POBOŻNOŚCl LUDOWEJ W ŻYCIU KOŚCIOŁA}

Każdy człowiek posiada różne możliwości intelektualne i inny poziom przyswajania wiedzy. Dlatego też od wieków ludzkość potrzebuje prostych i przejrzystych wyjaśnień. Najprawdopodobniej właśnie $\mathrm{z}$ tego powodu Jezus posługuje się przypowieściami, a więc gatunkiem

3 Zob. Sobór Watykański II, Konstytucja Duszpasterska o Kościele w świecie współczesnym Gaudium et Spes, w: Sobór Watykański II, Konstytucje, dekrety, deklaracje, Poznań 2002, n. 4.

4 Zob. Kongregacja ds. Kultu Bożego i Dyscypliny Sakramentów, Dyrektorium o pobożności ludowej i liturgii. Zasady i wskazania (dalej DPL), Poznań 2003, n. 64. 
literackim, w którym za pomocą sytuacji z życia codziennego obrazuje konkretną rzeczywistość duchową. Takie działanie miało na celu uprzystępnić uczniom treści, których dosłowne przyjęcie byłby wprost niemożliwe. „Przypowieści budują pomost między światem ludzkim i światem Boskim" ". Idąc dalej, trudno nie wspomnieć o Biblii pauperum, która w przystępny i powszechnie dostępny sposób, przybliżała egzegetyczne treści i pomagała $\mathrm{w}$ walce $\mathrm{z}$ herezjami ${ }^{6}$. Najbardziej przemawiające do serc wiernych homilie i kazania to te, w których autor zawarł proste przykłady i wyjaśnienia.

Można więc z łatwością dostrzec, że Lud Boży od zawsze potrzebuje przystępnych środków do tego, aby lepiej pojąć Boży plan zbawienia. Dlatego też synonimicznie traktowane terminy takie jak pobożność ludowa, religijność ludowa, katolicyzm ludowy czy chrześcijaństwo ludowe odnoszą się do aktualnie dostępnych „narzędzi” w danym kontekście kulturowym, które w możliwie najprostszy sposób pomagają w przeżywaniu wiary każdego człowieka. Aby jednak właściwie zrozumieć, czym jest pobożność ludowa warto odnieść się do definicji zawartej w dokumencie Kongregacji ds. Kultu Bożego i Dyscypliny Sakramentów pt.: „Dyrektorium o pobożności ludowej i liturgii”. Otóż pobożność ludowa to: „różne manifestacje kultyczne o charakterze prywatnym lub wspólnotowym, które $\mathrm{w}$ ramach wiary chrześcijańskiej są przeważnie wyrażane nie na sposób liturgii, lecz $\mathrm{w}$ formach wywodzących się z ducha poszczególnych narodów lub grup społecznych i ich kultury"7.

Szczególnie istotne w powyższej definicji są dwa sformułowania: „nie na sposób liturgii” oraz „wywodzących się z poszczególnych narodów lub grup społecznych i ich kultury”. Pierwsze z nich znajduje swoje odzwierciedlenie nie tylko w odniesieniu do osób ściśle związanych ze wspólnotą Kościoła, ale również grupy praktykujących swoją wiarę nieregularnie lub w ogóle niepraktykujących. Żyjąc w społeczności silnie naznaczonej wpływem kultury chrześcijańskiej, osoby te uczestniczą w praktykach o charakterze masowym i tradycyjnym. Jako przykład

${ }_{5}^{5}$ Zob. W. Pikor, Przypowieści Jezusa. Klucz narracyjny, Kielce 2011, s. 5.

${ }^{6}$ Por. R. Knapiński, Biblia Pauperum - rzecz o dialogu słowa i obrazu, w: Wizualizacja wiedzy Od Biblia Pauperum do hipertekstu, Lublin 2011, s. 17.

7 DPL, n. 9. 
może posłużyć nawiedzenie żłóbka w Okresie Narodzenia Pańskiego, Grobu Pańskiego w czasie świąt Wielkanocnych, tradycyjne poświęcenie pokarmów w Wielką Sobotę, które dla wielu niestety często stanowi kulminacyjny punkt Triduum Paschalnego, czy chociażby łamanie się opłatkiem w czasie wieczerzy wigilijnej. ${ }^{8}$ Wykonywanie tych czynności często ma charakter wyłącznie tradycyjny, pozbawiony ducha liturgii i domaga się pogłębienia oraz precyzyjnych wyjaśnień, co daje szeroką możliwość działań na polu pracy duszpasterskiej.

Drugie sformułowanie związane jest z kontekstem kulturowym danego narodu lub społeczności. Ów dany kontekst kulturowy to nic innego, jak rzeczywistość poszczególnych narodów, które wraz ze swoimi tradycjami i zwyczajami pragną podążać drogą wiary. „Religijność ludowa jest bowiem pierwszą i podstawową formą inkulturacji wiary: winna się zawsze poddawać kierownictwu liturgii i iść za jej wskazaniami, ale sama z kolei wzbogaca wiarę tym, co czerpie z serca"9. I tak oto niektóre zwyczaje, pochodzące z elementów tradycji danej społeczności, zakorzenione w sercach i umysłach wiernych, zostały wszczepione w liturgię Kościoła. Warto zatem aktualnie przyjrzeć się społeczności młodych ludzi i podjąć próbę dotarcia do nich z kerygmatem poprzez kulturę, w której żyją. Należy jednak pamiętać, że celem działań duszpasterskich, prowadzących do odnowy religijnej Kościoła jest formowanie właściwych postaw modlitewnych, które stanowią istotną część składową religii ${ }^{10}$. Nasuwa to wniosek, że aby pomóc młodym ludziom odnaleźć swoje miejsce w Kościele, należy najpierw nauczyć ich modlitwy. Jedną z metod może być posłużenie się praktykami pobożności ludowej, gdyż ich inicjatorami może być każdy, np. rodzina, przyjaciele lub osoby, które są już ugruntowane w wierze i mają należyte rozeznanie w misyjnej działalności Kościoła.

Droga pobożności ludowej wiedzie przez rozmaite formy, które w prosty sposób przekazują wiarę w Boga, miłość do Jezusa Chrystusa, otwarcie na Ducha Świętego, kult Matki Bożej i świętych oraz potrzebę

8 Por. M. Stępniak, Religijność ludowa jako droga przekazu tradycji, „Łódzkie Studia Teologiczne" 19 (2010), s. 277.

9 Zob. J. Ratzinger, Komentarz teologiczny, w: Kongregacja Nauki Wiary, Orędzie Fatimskie, Poznań, 2000, s. 32-44.

${ }^{10}$ Por. J. Przybyłowski, Jak modli się polska młodzież? Studium teologiczne, Warszawa 2013, s. 174. 
własnego rozwoju duchowego, nawrócenia i niesienia miłości bliźnim ${ }^{11}$. Jedną z nich są nabożeństwa. Stanowią one zewnętrzne ujawnienie pobożności i relacji między wiernym a Bogiem. Ich historia sięga początków chrześcijaństwa, natomiast dynamiczny rozwój nastąpił w wiekach średnich. Wówczas szczególne uznanie zyskały nabożeństwa ku czci Maryi, modlitwy w intencji dusz czyśćcowych, nabożeństwa zawierające motyw pasyjny takie, jak np. posty, biczowania i praktyki przypominające cierpienie Chrystusa oraz nabożeństwa eucharystyczne. Sobór Trydencki z kolei podjął się swoistego uporządkowania kwestii nabożeństw, gdyż mimo wielu korzyści z nich płynących, zaczęły przyćmiewać liturgię, co było i jest rzeczą niewłaściwą ${ }^{12}$.

Ważnym przełomem związanym z nabożeństwami był Sobór Watykański II, który w Konstytucji o Liturgii zaznaczył, iż:

Usilnie się zaleca nabożeństwa chrześcijańskiego ludu, pod warunkiem, że sprawuje się je zgodnie z przepisami i zasadami Kościoła, [...]. Szczególnym uznaniem cieszą się nabożeństwa partykularnych Kościołów, sprawowane z polecenia biskupów, zgodnie ze zwyczajami lub prawnie zatwierdzonymi księgami. Uwzględniając okresy liturgiczne, należy te nabożeństwa tak uporządkować, aby były zgodne ze świętą liturgią, z niej niejako wypływały i do niej wiernych prowadziły. Liturgia bowiem ze swej natury znacznie je przewyższa ${ }^{13}$.

Nabożeństwa mogą okazać się bardzo dużą podporą dla młodych ludzi w rozwoju ich wiary. Niezbędne jest jednak ich solidne przygotowanie. Dla przykładu warto zwrócić uwagę na nabożeństwo dziękczynne odprawiane 31 grudnia, na zakończenie roku kalendarzowego ${ }^{14}$. Może ono poprzedzać wspólną zabawę sylwestrową przygotowaną przez parafię. Dzięki temu rozwija się w młodych ludziach potrzebę dziękczynienia i refleksję nad tajemnicą czasu, odwołując się do kultury w której żyją. Równie atrakcyjną propozycję stanowi nabożeństwo „Via lucis” - Droga

11 Por. tamże, n. 6.

12 Por. Nabożeństwa ludu chrześcijańskiego, w: Leksykon liturgii, red. B. Nadolski, Poznań 2006, s. 996.

13 Zob. Sobór Watykański II, Konstytucja o Liturgii Świętej Sacrosanctum concilium, w: Sobór Watykański II, Konstytucje, dekrety, deklaracje, Poznań 2002, n. 13.

14 Zob. DPL, n. 114. 
światła, w którym wierni wspominają centralne wydarzenie wiary, jakim jest zmartwychwstanie Chrystusa oraz fakt bycia uczniami Pana ${ }^{15}$. Niezbędny jest w tym przypadku szereg działań precyzyjnie wyjaśniających wiernym znaczenie tego, w czym uczestniczą. Do tego nabożeństwa warto zaprosić przede wszystkim rodziców i chrzestnych pragnących ochrzcić swoje dziecko, tak aby przypomnieli sobie jak wielka godność związana jest $\mathrm{z}$ dziecięctwem Bożym.

Kolejną z form pobożności ludowej są zewnętrzne praktyki pobożności. Wśród nich należy wymienić: „teksty modlitw i pieśni, stosowanie się do okresów liturgicznych, nawiedzanie szczególnie znanych miejsc świętych, noszenie medalików, wyróżniające stroje i przestrzeganie lokalnych zwyczajów"16. Innymi słowy, zewnętrzne praktyki pobożności pomagają $\mathrm{w}$ przystępny sposób rozwinąć praktykę stałej modlitwy, do której zachęca św. Paweł nawołując: „nieustannie się módlcie!” (Tes 5,17). To właśnie dzięki nim wierni otrzymują środki do realizacji tego wezwania. Również wielu młodych ludzi entuzjastycznie uczestniczy w pielgrzymkach, nowennach, celebracjach ku czci Maryi i świętych, wspólnotowej modlitwie różańcowej, Koronce do Bożego Miłosierdzia czy Drodze Krzyżowej ${ }^{17}$. Jednakże często wspomniane praktyki nie mają swojego odzwierciedlenia w ich codziennym życiu, lub co gorsza nie prowadzą do właściwego pojmowania wspólnoty Kościoła. Młodzi ludzie zatrzymują się na „akcji” duszpasterskiej, nie podejmując stałej duchowej formacji, unikają moralnych pouczeń jakie daje Kościół oraz są niewrażliwi na jego problemy ${ }^{18}$.

Niezbędna jest więc świadomość, że praktyki pobożności ludowej nie zastępują życia liturgicznego Kościoła, lecz mogą służyć jego pogłębieniu. Dlatego też „konieczne jest rozeznanie duszpasterskie, by podtrzymywać i wspierać religijność ludową, a w razie potrzeby oczyszczać i pogłębiać zmysł religijny, z którego wyrastają te formy pobożności, oraz

15 Zob. DPL, n. 153.

16 Zob. DPL, n. 8.

17 Por. Konferencja Episkopatu USA, Praktyki pobożności ludowej: podstawowe pytania i odpowiedzi, „Salvatoris Mater” 5/4 (2003), s. 341.

18 Por. J. Baniak, Kościół instytucjonalny w krytycznym spojrzeniu dzisiejszych katolików polskich, „Przegląd Religioznawczy” 2 (2011), s. 99. 
kierować je do głębszego poznawania misteriów Chrystusa" ${ }^{19}$. Bezpieczną drogą praktykowania pobożności ludowej jest zatem stałe odniesienie do Ewangelii. Modlitwa chrześcijańska powinna w sposób bezpośredni lub pośredni odnosić się do Pisma Świętego ${ }^{20}$. To ono bowiem zawiera objawione słowo Boże, dzięki któremu Kościół zna kierunek swoich działań i może przynosić ich upragnione owoce ${ }^{21}$.

Pobożność ludowa uzewnętrznia się przez słowa, gesty, teksty i formuły, śpiewy i muzykę, wizerunki religijne, miejsca i czasy. Elementy te, mimo iż naznaczone głębokim uczuciem, zawsze powinny być starannie dobrane, zachowywać swój styl i prostotę. Potrzeba zatem pieczołowitej troski o to, aby przekazywane treści klarownie wyrażały prawdy wiary i głębię misteriów Chrystusa. W przeciwnym razie bogactwo ekspresji ciała, gesty i symbole mogłoby być sprowadzone jedynie do zewnętrznych, pustych zwyczajów, a co gorsza, nawet do zabobonów ${ }^{22}$. Innymi słowy w centrum pobożności ludowej „należy stawiać Chrystusa i Jego tajemnicę, bowiem Chrystus jest w centrum naszej wiary i sprawowanej liturgii. W ten sposób Chrystus stanie się powoli centrum pobożności, modlitwy i On będzie kształtował duchowość uczestników nabożeństw"23.

Pomocą w realizacji tego zadania mogą okazać się błogosławieństwa. Stanowią one przykład wzajemnego przenikania się pobożności ludowej i liturgii Kościoła ${ }^{24}$. Oprócz tego, jak wskazuje ks. prof. Konecki: „wyrażają prawdę tkwiącą w samym sercu wiary chrześcijańskiej: o obecności Boga w świecie i w historii, o przynależności człowieka do Boga, o autonomii świata wobec Boga, ale i o kruchości świata bez Boga”25. Dzięki błogosławieństwom młodzi ludzie mogą z powodzeniem na nowo

19 Zob. Katechizm Kościoła Katolickiego, Poznań 2002, n. 1675-1676.

${ }^{20}$ Zob. DPL, n. 12.

${ }^{21}$ Por. M. Pyc, Pobożność ludowa a sensus fidei, „Studia Gnesnensia” 27 (2013), s. 48 .

${ }_{22}$ Por. DPL, n. 15.

${ }_{23}$ Zob. B. Nadolski, Biuletyn Liturgiczny (97), „Collectanea Theologica” 68 (1998), Z. 4, s. 145 .

${ }^{24}$ Por. DPL, n. 33.

${ }_{25}$ Zob. K. Konecki, Błogosławieństwa w życiu Kościoła, „Studia Włocławskie” 5 (2002), s. 151. 
odkryć, jak bardzo ich rzeczywistość zależy od Bożej Opatrzności. Aby tak się stało, niezbędna jest popularyzacja błogosławieństw w rodzinach, które są naturalnym środowiskiem młodych osób. Głowa rodziny lub jej starsi członkowie poprzez „błogosławienie domu, rodziny, narzeczonych, dziecka chorego, dzieci przed podróżą, wyjazdem na ferie, syna bądź córki obchodzących osiemnastkę, ludzi w podeszłym wieku, pokarmów przed rodzinnym posiłkiem" ${ }^{26}$, mogą znacząco wpłynąć na swoich bliskich. Dzięki temu osoby zagubione lub nieufne wobec praktyk religijnych niejako automatycznie staną się uczestnikami liturgii Kościoła. Dodatkowym atutem błogosławieństw jest to, że „nie zawsze muszą mieć formę długiej modlitwy (formuły). Często będzie to zwykłe przeżegnanie się lub przeżegnanie drugiej osoby, względnie rzeczy, lub uczynienie znaku krzyża na czole dziecka przez rodziców czy opiekunów”27.

Jak można zauważyć pobożność ludowa jest rzeczywistością ciągle aktualną i potrzebną. Stanowi ona przystępną pomoc, dzięki której osoby mające problem z podejmowaniem praktyk religijnych mogą rozmiłować się w liturgii Kościoła i zapragnąć bliskości Chrystusa w swoim życiu. Odwołując się do sfery uczuć i aktualnych potrzeb z pewnością docenią bogactwo Kościoła, na które w subtelny sposób rzuca światło pobożność ludowa. Warto zatem dbać o to, aby ta forma wyznawania swojej wiary nie była deprecjonowana lub postrzegana jako religijny folklor czy infantylizm, gdyż może ona stanowić konkretną drogę do odnowy Kościoła. Pobożność ludowa bowiem często dociera daleko poza mury kościołów, wychodzi do przydrożnych kaplic, znajduje swoje miejsce w domach, na ulicach wsi i miast.

\section{DUSZPASTERSTWO ON-LINE JAKO WSPÓŁCZESNE NARZĘDZIE EWANGELIZACJI}

Obok pobożności ludowej istnieje wiele innych środków, dzięki którym współcześni ludzie mogą poznać Boga i Kościół. Wielu duszpasterzy chwytając się niemal każdej możliwości dotarcia do wierzących

${ }^{26}$ Zob. tamże, s. 154.

27 Zob. tenże, Sprawowanie błogosławieństw wydarzeniem kościelnym, „Seminare. Poszukiwania naukowe" 13 (1997), s. 16. 
i niewierzących, często posługuje się niekonwencjonalnymi metodami. Niektórzy z nich korzystają z ulicznej ewangelizacji ${ }^{28}$, organizują koncerty, reżyserują pantomimy, budują mobilne konfesjonały lub czekają na wiernych w miejscach publicznych. Wyjątkowym narzędziem, którym mogą posłużyć się dziś uczniowie Chrystusa, są środki społecznego przekazu. Ogrywają one niezwykle istotną rolę w procesie ewangelizacji i odnowy Kościoła. „Ze swej natury zdolne są bezpośrednio wpływać nie tylko na poszczególnych ludzi, lecz także na zbiorowości i na całą społeczność ludzką"29. Narzędzia takie jak prasa, kino, radio, telewizja czy Internet, stanowią bardzo ważny element kształtowania ludzkiej duchowości. Oprócz tego, jak wskazał papież Paweł II:

Środki te, w służbie Ewangelii, dają możliwość rozszerzenia prawie bez ograniczeń obszaru słuchania Słowa Bożego, docierając z Dobrą Nowiną do milionów ludzi. Kościół czułby się winny przed Bogiem, gdyby nie używał tych potężnych środków, które ludzki intelekt coraz bardziej udoskonala. Za ich pośrednictwem Kościół „rozgłasza publicznie” (por. Mt 10, 27; Łk 12,3) orędzie, którego jest depozytariuszem. W nich znajduje nowoczesną i skuteczną wersję „pulpitu”. Dzięki nim może mówić do tłumów ${ }^{30}$.

Nietrudno dostrzec, że aktualnie najważniejszym z środków społecznego przekazu jest Internet. Większość współczesnych Polaków (jak podaje na swoim Tweeterze Ministerstwo Cyfryzacji) traktuje go jako nieodzowną część swojego życia ${ }^{31}$. Internet jest bardzo dobrym narzędziem komunikacyjnym, pozwalającym na kontakt osób z różnych stron świata w czasie rzeczywistym. W tym celu wykorzystuje się aplikacje (np. WhatsApp, Skype, Messenger) lub portale społecznościowe takie jak Facebook, Instagram, Tweeter i tym podobne. Ponadto szczególnie przydatne w ko-

28 Por. T. Wielebski, Nawrócenie pastoralne $i$ duszpasterstwo misyjne parafii w Polsce, „Teologia i Człowiek” 45 (2019), n. 1, s. 116.

${ }^{29}$ Zob. Sobór Watykański II, Dekret o środkach społecznego przekazu Inter Mirifica, w: Sobór Watykański II, Konstytucje, dekrety, deklaracje, Poznań 2002, n. 1.

${ }^{30}$ Paweł VI, Adhortacja Apostolska o Ewangelizacji w świecie współczesnym Evangelii nuntiandi, Wrocław 2001, n. 45.

31 Zob. Komunikat Ministerstwa Cyfryzacji, w: https://twitter.com/MC_GOV_PL/ status/1146354096967954432?s=20 (dostęp: 24.05.2020). 
munikacji stają się programy umożliwiające rozmowę za pomocą kamery internetowej. Internet pozwala również na swobodne oglądanie subiektywnie wyselekcjonowanych treści, czytanie książek w postaci e-booków, korzystanie z audiobooków i wiele innych. Oprócz tego „Internet posiada pewne uderzające cechy. Jest natychmiastowy, bezpośredni, ma światowy zasięg, jest zdecentralizowany, interaktywny, nieskończenie rozszerzalny co do treści i oddźwięku, łatwo dostosowujący się i adaptujący w znacznym stopniu. Jest egalitarny, to znaczy - każdy posiadający odpowiedni sprzęt i umiarkowane umiejętności techniczne może być aktywnie obecny w cyberprzestrzeni, ogłaszać swoje przesłanie światu i domagać się uwagi" ${ }^{2}$. Nie dziwi więc ogromny rozwój vlogów, blogów i innych form, poprzez które ludzie zaznaczają dziś swoją obecność w świecie.

Wobec tak wielkiej zdobyczy techniki jaką jest Internet, Kościół nie mógł pozostać bierny. Dlatego niemal od początku istnienia Sieci wykorzystuje jej potencjał. Już bowiem 24 grudnia 1995 roku powstała oficjalna strona internetowa Stolicy Apostolskiej. Zawierała ona zdjęcie papieża Jana Pawła II oraz jego orędzie związane ze świętami Narodzenia Pańskiego ${ }^{33}$. Wśród wielu korzyści, które płyną z Internetu w wymiarze religijnym, można wymienić: „dostęp do wiadomości, tj. do ważnych zasobów religijnych i duchowych, bibliotek, muzeów, miejsc kultu, dokumentów, nauczania Magisterium, pism Ojców i Doktorów Kościoła”34. Oprócz tego aktualnie powstało wiele aplikacji umożliwiających swobodne korzystanie z Pisma Świętego oraz dających dostęp do komentarzy biblijnych. Często pozwalają one zaplanować lekturę Biblii, podają aktualne przesłanie papieża, pomagają poznać żywoty świętych, zawierają przypomnienia o modlitwie, a nawet pozwalają na modlitwę Liturgią Godzin. Ich głównym atutem jest to, że do swojego działania wymagają jedynie urządzenia wyposażonego w Internet (np. smartfona lub tableta), a więc współcześnie można z nich korzystać niemal wszędzie.

32 Zob. Papieska Rada ds. Środków Społecznego Przekazu, Etyka w Internecie, „Biuletyn KAI”, n. 7, w: https://ekai.pl/dokumenty/etyka-w-internecie (dostęp: 19.05.2020).

${ }^{33}$ Por. P. Sołga, Kościół katolicki wobec Internetu. Zarys problematyki w ujęciu historycznym, „Res Gestae” 2 (2016), s. 148.

${ }^{34}$ Zob. Papieska Rada ds. Środków Społecznego Przekazu, Kościół a Internet, „Biuletyn KAI” n. 5, https://ekai.pl/dokumenty/kosciol-a-internet (dostęp: 22.05.2020). 
Na szczególną uwagę zasługuje rozwój platformy YouTube. Pozwala ona umieszczać, oglądać i komentować filmy w Sieci. W pierwszych latach jej funkcjonowania przesyłane treści były objęte limitem czasowym (nagrania nie mogły przekraczać określonego przez serwis czasu), a do dziś istnieją obostrzenia związane z prawami autorskimi. Serwis YouTube dostępny jest niemal we wszystkich szerokościach geograficznych, a podawane użytkownikom treści dostosowywane są ich lokalizacji ${ }^{35}$. Autorem zawartości serwisu YouTube może być każdy, kto chce publicznie dzielić się swoja pasją, wiedzą, twórczością lub poglądami. Do nagrań często wystarcza smartfon z opcją nagrywania video. Tak wielkie możliwości doprowadziły do powstania wielu programów partnerskich, dzięki którym możliwym stało się czerpanie korzyści finansowych z przesłanych przez siebie materiałów, np. poprzez wyświetlanie w czasie ich trwania reklam, bannerów oraz sprzedawanie lub wypożyczanie treści. Skutkiem takich działań było powstanie zawodu youtubera, czyli osoby, która zarabia na zamieszczaniu materiałów wideo ${ }^{36}$. Takich osób nie brakuje także wśród duchownych i świeckich, którzy posługując się platformą YouTube podejmują starania, aby z Dobrą Nowiną o zbawieniu dotrzeć do wszystkich ludzi, szczególnie znajdujących się na peryferiach Kościoła.

W dobie pandemii koronawirusa Kościół na pewien czas niemal całkowicie przeniósł swoją aktywność duszpasterską do Internetu, co pozwoliło dokładnie prześledzić $\mathrm{w}$ jakim wymiarze korzysta on $\mathrm{z}$ dobrodziejstw cyberprzestrzeni. W czasie, gdy w kościołach i miejscach publicznych wierni nie mogli brać czynnego udziału w praktykach religijnych, wielu duszpasterzy spontaniczne postanowiło podjąć się transmisji on-line, tak aby każdemu umożliwić trwanie we wspólnotowej modlitwie. Najczęściej w tym celu wykorzystywano serwisy Facebook i YouTube, które oprócz możliwości przesłania utworzonych wcześniej treści oferują także transmisję wydarzeń na żywo. Pozwalało to na uczestnictwo w Mszach Świętych, nabożeństwach lub rekolekcjach nie tylko regularnie praktykującym katolikom, ale wszystkim, którzy zostali objęci zasięgiem

35 Por. A. Stępniak, Portale społecznościowe a postawy i zachowanie przedsiębiorcze. Studium przypadku serwisu YouTube, „Zeszyty Naukowe Politechniki Częstochowskiej” 31 (2018), s. 233.

${ }^{36}$ Por. tamże, s. 235. 
dodawanych filmów czy postów. Dzięki temu wiele osób dalekich Kościołowi mogło na nowo podjąć refleksję nad swoją kondycją duchową.

Wśród internetowych inicjatyw duszpasterskich w czasie trwania kulminacyjnego etapu epidemii można było znaleźć następujące: „Na stronie Facebooka codziennie umieszczane są czytania i Ewangelia na dany dzień”; „Transmisja on-line modlitwy różańcowej codziennie o godz. 20.30”; „Na stronie Facebooka parafialnego codziennie umieszczane są czytania i Ewangelia na dany dzień; jak również rekolekcje prowadzone przez różne ośrodki ewangelizacyjne oraz linki do wydarzeń z naszej Diecezji”; „transmisja Drogi krzyżowej i Gorzkich żali”; „Codzienna aktualizacji informacji na stronie parafii oraz na Facebooku parafialnym”" ${ }^{37}$.

Jak widać, dzięki cyberprzestrzeni Kościół posiada wszelkie możliwe środki, aby jeszcze lepiej realizować swoją misję, tzn. sprawiać, by „Słowo Pańskie szerzyło się i rozsławiało” (2 Tes 3,1), a „królestwo Boże było głoszone i utwierdzane na całej ziemi”38. Za pomocą Internetu współcześni uczniowie Chrystusa niosą orędzie Ewangelii wszystkim narodom docierając do wszelkich grup etnicznych i kulturowych. Również w kontekście Kościoła w Polsce, sieć internetowa stanowi atrakcyjne i skuteczne narzędzie duszpasterskie. Za jego pomocą wierni mogą pozostawać w stałej łączności ze swoją parafią poprzez śledzenie ogłoszeń duszpasterskich, galerii zdjęć lub aktualności umieszczanych na jej stronie internetowej. Osoby rozwijające praktykę częstej modlitwy mogą skorzystać ze specjalnie przygotowanych aplikacji. Chętnym do pogłębienia swojej wiary lub wiedzy religijnej z powodzeniem może posłużyć platforma YouTube. Natomiast osoby zagubione i poszukujące odpowiedzi na nurtujące ich pytania mogą z łatwością nawiązać kontakt z kompetentnymi osobami. Mądrze wykorzystana przestrzeń Internetu stanowi więc bardzo konkretną pomoc w odnowie Kościoła i nawróceniu pastoralnym szczególnie młodego pokolenia.

37 Zob. Komunikat Diecezji Włocławskiej, Inicjatywy duszpasterskie w parafiach diecezji włocławskiej w okresie epidemii (aktualizacja), w: https://www.diecezja.wloclawek. pl/pl,news2,inicjatywy_duszpasterskie_w_parafiach_diecezji_wloclawskiej_w_okresie_epidemii_aktualizacja_,1304.html (dostęp: 20.05.2020).

${ }_{38}$ Zob. Sobór Watykański II, Dekret o misyjnej działalności kościoła Ad Gentes Divinitus, w: Sobór Watykański II, Konstytucje, dekrety, deklaracje, Poznań 2002, n. 1. 


\section{NIEBEZPIECZEŃSTWA ZWIAZZANE Z POBOŻNOŚCIĄ LUDOWĄ I DUSZPASTERSTWEM ON-LINE}

Bez wątpienia obie z wcześniej wymienionych form działalności duszpasterskiej Kościoła niosą za sobą bardzo wiele korzyści. Ich główny atut polega na tym, że w znacznym stopniu przenikają ludzką codzienność. Oprócz tego, są powszechnie dostępne, a treść którą niosą jest bardzo przystępna, dzięki czemu bez trudu może korzystać z nich każdy. Niestety obok wielu zalet, posiadają także cechy, które nie tylko mogą okazać się nieskuteczne $\mathrm{w}$ prowadzeniu wiernych do Boga, ale wręcz mogą utrudnić spotkanie z Nim. Niezbędne jest zatem dostrzeżenie zagrożeń, które płyną z niewłaściwie rozumianej pobożności ludowej lub złego wykorzystania Internetu w działaniach duszpasterskich, ich ocena i wysnucie istotnych wniosków.

Do wykazania błędów związanych z omawianymi formami działalności duszpasterskiej Kościoła, niezbędna jest świadomość znaczenia słowa „duszpasterstwo”. Otóż według ks. prof. Kamińskiego, jest ono „zorganizowaną działalnością zbawczą Kościoła urzeczywistniającą w służbie człowieka zbawcze dzieło Chrystusa przez głoszenie słowa Bożego, liturgię, posługę pasterską i świadectwo życia chrześcijańskiego"39. Już pierwsze słowo powyższej definicji odkrywa ważny aspekt duszpasterstwa - nie może być ono chaotyczne, niezaplanowane, dalekie od poprawnej wizji teologicznej Kościoła, ale zorganizowane ${ }^{40}$. Dlatego też pierwszym niebezpieczeństwem dotyczącym zarówno pobożności ludowej jak i duszpasterstwa internetowego jest przesadna improwizacja i źle rozumiana spontaniczność. Człowiek w swoim życiu do właściwego funkcjonowania potrzebuje planu i dokonania wyboru spośród różnych możliwości postępowania. Podobnie Kościół - aby był skuteczny powinien opierać się na planowaniu duszpasterskim, którego celem jest poszukiwanie woli Bożej, a więc „odkrycie tego, co Bóg chce, aby Kościół uczynił”41.

${ }^{39}$ Zob. Duszpasterstwo, w: Leksykon teologii pastoralnej, red. R. Kamiński, W. Przygoda, M. Fijałkowski, Lublin 2006, s. 201.

${ }^{40}$ Por. T. Wielebski, Uczeń Chrystusa a program duszpasterski Kościoła Katolickiego w Polsce na początku XXI wieku, „Warszawskie Studia Teologiczne” 21 (2008), s. 99.

${ }^{41}$ Zob. A. Sapieha, Planowanie duszpasterskie w praktyce, "Studia Paradyskie” 23 (2013), s. 138. 
Kolejnym z zagrożeń jest „niewystarczająca znajomość takich podstawowych zasad wiary chrześcijańskiej, jak zbawcze znaczenie zmartwychwstania Chrystusa, znaczenie przynależności do Kościoła, osoba i działanie Ducha Świętego, brak odpowiednich proporcji między kultem świętych i świadomością bezwzględnej wyższości roli tajemnicy Jezusa Chrystusa; słaby kontakt z Pismem Świętym, brak korzystania ze świętych sakramentów Kościoła; tendencja do oddzielania przeżyć kultycznych i zaangażowania $\mathrm{w}$ życie chrześcijańskie; utylitarystyczne rozumienie różnych form pobożności; stosowanie znaków, gestów i formul, którym przypisuje się znaczenie nadzwyczajne do tego stopnia, że wynajduje się nawet gesty spektakularne" ${ }^{\text {"2 }}$. Oznacza to, że Kościół przez swoich pasterzy powinien czuwać nad kompetencjami osób angażujących się w promowanie pobożności ludowej i duszpasterstwa internetowego. Brak należytej wiedzy i rozeznania teologicznego, może wywołać fatalne skutki w postaci zamętu i niepokoju ich odbiorców.

Następnym niebezpieczeństwem, które szczególnie dotyczy duszpasterstwa on-line, jest fakt, że niektóre ze stron internetowych, mimo iż uchodzą za katolickie, „przekazują ekscentryczne interpretacje doktrynalne, dziwaczne praktyki pobożne, zachwalają różne ideologie niezgodne $\mathrm{z}$ nauką Kościoła”" ${ }^{43}$. To sprawia, że wiele osób nieugruntowanych w wierze może mieć problem z odróżnieniem nauczania Kościoła katolickiego od nauczania np. protestanckiego lub co gorsza prowadzonego przez różnego rodzaju sekty. Oprócz tego, wielu użytkowników poszukujących odpowiedzi na nurtujące ich pytania z zakresu wiary i religii, poprzez niewłaściwą weryfikację źródeł, może wybierać to, co najbardziej odpowiada ich indywidualnym oczekiwaniom, lecz nie niesie ze sobą obiektywnej prawdy ${ }^{44}$. Dotyczy to również osób, które upubliczniają swoje treści społeczności internetowej. Wielkim zagrożeniem może być to, że całą uwagę widzów, czytelników lub słuchaczy skupiają na sobie, swoich poglądach, zainteresowaniach i przemyśleniach, a nie na osobie Chrystusa. Skandalicznym jest

${ }^{42}$ DPL, n. 65.

${ }^{43}$ Zob. Papieska Rada ds. Środków Społecznego Przekazu, Kościół a Internet, „Biuletyn KAI” n. 8, w: https://ekai.pl/dokumenty/kosciol-a-internet (dostęp: 22.05.2020).

${ }^{44}$ Por. A. Domaszak, Internet dobrodziejstwem i zagrożeniem: formacyjne wyzwania dla seminariów duchownych, „Seminare. Poszukiwania naukowe” 33 (2013), s. 68-69. 
wykorzystywanie Kościoła w celach zarobkowych lub dla rozwoju własnej kariery czy zaspokojenia nieuporządkowanych ambicji.

W kontekście niebezpieczeństwa, jakie niesie za sobą duszpasterstwo internetowe warto zwrócić także uwagę na wypowiedź papieża Franciszka, który 17 kwietnia 2020 roku, w czasie porannej Eucharystii, w homilii powiedział:

Przed Wielkanocą, kiedy pojawiła się informacja, że będę ją celebrował w pustej bazylice św. Piotra, pewien bardzo dobry biskup uczynił mi zarzut: „Dlaczego, w tak wielkiej bazylice, nie może być choćby przynajmniej 30 osób, aby można było widzieć wiernych? Przecież to nie będzie niebezpieczne". Zastanawiałem się nad tym i pomyślałem, że on powiedział mi: „Uważaj, abyś nie zwirtualizował Kościoła, sakramentów, ludu Bożego". Kościół, sakramenty, Boży lud są bowiem czymś konkretnym ${ }^{45}$.

Oprócz wspomnianych zagrożeń związanych z niewłaściwie pojmowaną pobożnością ludową i duszpasterstwem realizowanym w cyberprzestrzeni, z powodzeniem można by wskazać jeszcze wiele innych. Wszystkie z nich domagają się wzmożonej czujności osób odpowiedzialnych za organizację duszpasterstwa w Kościele katolickim, a mówiąc precyzyjniej - ich nawrócenia.

„Czy może niewidomy prowadzić niewidomego?”(Łk 6,39). Oczywistym jest, że nie, dlatego podstawowym działaniem mającym na celu uniknięcie błędów, nadużyć i zagrożeń w duszpasterstwie jest proces rozeznania, oczyszczenia i reformy. Jego inicjatorem powinien być pasterz kościoła lokalnego, którego obowiązkiem jest pomoc w osiąganiu dojrzałości wiernych poprzez różne formy uczestnictwa w życiu Kościoła ${ }^{46}$.

\section{PODSUMOWANIE}

Celem niniejszej pracy było ukazanie pobożności ludowej i duszpasterstwa on-line jako przestrzeni odnowy wiary i religijności młodych

${ }^{45}$ Zob. Komunikat Stolicy Apostolskiej, Papież: módlmy się za kobiety w ciąży, uważajmy na wirtualne przeżywanie wiary, w: https://www.vaticannews.va/pl/papiez-franciszek/msza-w-domu-sw-marty/2020-04/papiez-modlmy-sie-za-kobiety-w-ciazyuwazajmy-na-wirtualne-prz.html (dostęp: 22.05.2020).

${ }^{46}$ Zob. Franciszek, Adhortacja Apostolska o głoszeniu Ewangelii w dzisiejszym świecie Evangelii Gaudium, Kraków 2013, n. 31. 
osób, znajdujących się na peryferiach wspólnoty Kościoła w Polsce. Omówione formy działań duszpasterskich cechują się przystępnością, prostotą i powszechnością. Pobożność ludowa za pomocą odniesień do sfery uczuciowej i emocjonalnej, stanowi dobry fundament dla pogłębienia życia modlitewnego i liturgicznego młodych osób. Oprócz tego uczy refleksji nad dziełem zbawczym i nauczaniem Jezusa Chrystusa. Internet z kolei, jako aktualnie najbardziej powszechny środek masowego przekazu, umożliwia ludziom łatwy dostęp do religijnych treści. Niezależnie od etapu ich rozwoju duchowego, poprzez platformy, portale, aplikacje i wiele innych, niesie konkretną pomoc w poznawaniu prawd wiary, Ewangelii, nauczania Kościoła, a nade wszystko samego Boga. Wspólną cechą omawianych pojęć jest także to, że wykraczają poza mury kościołów, przez co mogą przenikać codzienne życie młodych Polaków, bez względu na miejsca ich przebywania.

Drugim zadaniem tegoż artykułu było zwrócenie uwagi na niebezpieczeństwa płynące z niewłaściwego wykorzystania Internetu i form pobożności ludowej w duszpasterstwie. Zła organizacja, brak podstawowej wiedzy teologicznej, chęć zaspokojenia własnych ambicji, czy pokusa wirtualizacji Kościoła, to niektóre z zagrożeń zakłócających przekaz Bożego objawienia. Niezbędne są zatem działania duszpasterskie, dzięki którym w przyszłości będzie można uniknąć tego rodzaju błędów. Wśród nich można wymienić: planowanie działalności duszpasterskiej Kościoła, związane chociażby z realizacją programów duszpasterskich ${ }^{47}$; troska o właściwe kompetencje teologiczne duszpasterzy, a nade wszystko stałe odniesienie do nauczania Chrystusa i Kościoła powszechnego. Problem odnowy życia religijnego młodych ludzi pozostaje jednak otwarty i domaga się stałej weryfikacji.

\section{BIBLIOGRAFIA}

Franciszek, Adhortacja apostolska o głoszeniu Ewangelii w dzisiejszym świecie Evangelii Gaudium, Kraków 2013.

Jan Paweł II, Grzech jako „alienacja” człowieka, w: Jan Paweł II, Dzieła zebrane, t. 6, Katechezy, cz. I, Kraków 2007, s. 750-753.

47 Zob. T. Wielebski, Uczeń Chrystusa a program duszpasterski Kościoła katolickiego w Polsce na początku XXI wieku, „Warszawskie Studia Teologiczne” 21 (2008), s. 99. 
Katechizm Kościoła Katolickiego, Poznań 2002.

Komunikat Stolicy Apostolskiej, Papież: módlmy się za kobiety w ciąży, uważajmy na wirtualne przeżywanie wiary, w: https://www.vaticannews.va/pl/papiez-franciszek/msza-w-domu-sw-marty/2020-04/papiez-modlmy-sie-za-kobiety-w-ciazyuwazajmy-na-wirtualne-prz.html (dostęp: 22.05.2020).

Konferencja Episkopatu USA, Praktyki pobożności ludowej: podstawowe pytania i odpowiedzi, „Salvatoris Mater” 5/4 (2003), s. 341-355.

Kongregacja ds. Kultu Bożego i Dyscypliny Sakramentów, Dyrektorium o pobożności ludowej i liturgii. Zasady i wskazania, Poznań 2003.

Papieska Rada ds. Środków Społecznego Przekazu, Etyka w Internecie, „Biuletyn KAI”, w: https://ekai.pl/dokumenty/etyka-w-internecie (dostęp: 19.05.2020).

Papieska Rada ds. Środków Społecznego Przekazu, Kościót a Internet, „Biuletyn KAI”, w: https://ekai.pl/dokumenty/kosciol-a-internet (dostęp: 22.05.2020).

Paweł VI, Adhortacja apostolska o Ewangelizacji w świecie współczesnym Evangelii nuntiandi, Wrocław 2001.

Sobór Watykański II, Dekret o misyjnej działalności kościoła Ad Gentes Divinitus, w: Sobór Watykański II, Konstytucje, dekrety, deklaracje, Poznań 2002, s. 433-471.

Sobór Watykański II, Dekret o środkach społecznego przekazu Inter Mirifica, w: Sobór Watykański II, Konstytucje, dekrety, deklaracje, Poznań 2002, s. 87-94.

Sobór Watykański II, Konstytucja duszpasterska o Kościele w świecie współczesnym Gaudium et Spes, w: Sobór Watykański II, Konstytucje, dekrety, deklaracje, Poznań 2002, s. 526-604.

Sobór Watykański II, Konstytucja o liturgii świętej Sacrosanctum concilium, w: Sobór Watykański II, Konstytucje, dekrety, deklaracje, Poznań 2002, s. 48-78.

Baniak J., Kościół instytucjonalny w krytycznym spojrzeniu dzisiejszych katolików polskich, „Przegląd Religioznawczy” 2 (2011), s. 91-112.

Domaszak A., Internet dobrodziejstwem i zagrożeniem: formacyjne wyzwania dla seminariów duchownych, „Seminare. Poszukiwania naukowe” 33 (2013), s. 63-79.

Główny Urząd Statystyczny, Życie religijne w Polsce. Wyniki badania spójności społecznej 2018, w: https://stat.gov.pl/obszary-tematyczne/inne-opracowania/wyznania-religijne/zycie-religijne-w-polsce-wyniki-badania-spojnosci-spolecznej-2018,8,1. html (dostęp: 25.05.2020).

Knapiński R., Biblia Pauperum - rzecz o dialogu słowa i obrazu, w: Wizualizacja wiedzy od Biblia Pauperum do hipertekstu, Lublin 2011, s. 10-36.

Komunikat Diecezji Włocławskiej, Inicjatywy duszpasterskie w parafiach diecezji włocławskiej w okresie epidemii (aktualizacja), w: https://www.diecezja.wloclawek.pl/pl, news2,inicjatywy_duszpasterskie_w_parafiach_diecezji_wloclawskiej_w_okresie_epidemii_aktualizacja_,1304.html (dostęp: 20.05.2020).

Komunikat Ministerstwa Cyfryzacji, w: https://twitter.com/MC_GOV_PL/status/114635 4096967954432 ?s=20 (dostęp: 24.05.2020).

Konecki K., Błogosławieństwa w życiu Kościoła, „Studia Włocławskie” 5 (2002), s. $150-160$. 
Konecki K., Sprawowanie błogosławieństw wydarzeniem kościelnym, „Seminare. Poszukiwania naukowe" 13 (1997), s. 13-22.

Leksykon liturgii, red. B. Nadolski, Poznań 2006.

Leksykon teologii pastoralnej, red. R. Kamiński, W. Przygoda, M. Fijałkowski, Lublin 2006.

Nadolski B., Biuletyn Liturgiczny (97), „Collectanea Theologica” 68 (1998), z. 4, s. 135-152.

Pikor W., Przypowieści Jezusa. Klucz narracyjny, Kielce 2011.

Pyc M., Pobożność ludowa a sensus fidei, „Studia Gnesnensia” 27 (2013), s. 47-57.

Ratzinger J., Komentarz teologiczny, w: Kongregacja Nauki Wiary, Orędzie Fatimskie, Poznań 2000, s. 32-44.

Sapieha A., Planowanie duszpasterskie w praktyce, „Studia Paradyskie” 23 (2013), s. 137-156.

Sołga P., Kościół katolicki wobec Internetu. Zarys problematyki w ujęciu historycznym, „Res Gestae" 2 (2016) s. 145-161.

Stępniak A., Portale społecznościowe a postawy i zachowanie przedsiębiorcze. Studium przypadku serwisu YouTube, „Zeszyty Naukowe Politechniki Częstochowskiej” 31 (2018), s. 232-242.

Stępniak M., Religijność ludowa jako droga przekazu tradycji, „Łódzkie Studia Teologiczne” 19 (2010), s. 276-283.

Wielebski T., Nawrócenie pastoralne i duszpasterstwo misyjne parafii w Polsce, „Teologia i Człowiek" 45 (2019), n. 1, s. 105-119.

Wielebski T., Uczeń Chrystusa a program duszpasterski Kościoła Katolickiego w Polsce na początku XXI wieku, „Warszawskie Studia Teologiczne” 21 (2008), s. 97-112. 